\title{
New species and notes of Colletotrichum on daylilies (Hemerocallis spp.)
}

\author{
Youlian Yang ${ }^{1,2}$, Zuoyi Liu ${ }^{1}$, Lei Cai ${ }^{3}$ \& Kevin D. Hyde ${ }^{4}$ \\ ${ }^{1}$ Guizhou Key Laboratory of Agricultural Biotechnology, Guizhou Academy of Agricultural Sciences, Guiyang, Guizhou \\ 550006, P. R. China; ${ }^{2}$ Department of Life Science, Liupanshui Normal University, Shuicheng, Guizhou 553006, P. R. China; \\ ${ }^{3}$ State Key Laboratory of Mycology, Institute of Microbiology, Chinese Academy of Sciences, No.10, North 4th Ring \\ Road West, Beijing 100190, P. R. China; ${ }^{4}$ Institute of Excellence in Fungal Research, School of Science, Mae Fah Luang \\ University, Chiang Rai 57100, Thailand; Visiting Professor, Botany and Microbiology Department, College of Science, King \\ Saud University, Riyadh, Saudi Arabia
}

Author for correspondence: Kevin D. Hyde, e-mail: kdhyde3@gmail.com

\begin{abstract}
Nine Colletotrichum strains were isolated from diseased and dead stalks of Hemerocallis species (daylilies) from Guizhou, Guangxi, and Liaoning provinces in China. Morphological characteristics and multilocus phylogenetic analysis of ACT, CHS I, GPDH, ITS, and TUB 2 indicate that these strains represent four taxa. Colletotrichum hemerocallidis is a new species that is described, illustrated, and compared with similar species. Colletotrichum gloeosporioides, C. liriopes, and C. spaethianum are also recorded on Hemerocallis species.
\end{abstract}

Key words: Anthracnose, multilocus phylogeny, systematics.

\section{INTRODUCTION}

Hemerocallis species (including H. fulva (L.) Linn., H. citrina Baroni, and other species or cultivars) are economically important as food plants in China, Japan, Korea, Thailand, and Vietnam, being known as "yellow flower vegetables" or "golden needles" in China (Zhou et al., 1994; Staples \& Kristiansen, 1999; Zhang \& Chen, 2008). Species are also cultivated and bred worldwide for their showy flowers and ability to adapt to a wide range of soils and climates (Munson, 1989; Tomkins et al., 2010), and are used as Traditional Chinese Medicine (Zhu et al., 2008; Ma et al., 2010).

Hemerocallis production has often been limited by anthracnose disease (Jiang et al., 1993). Disease outbreaks can be severe with $100 \%$ of some ornamental Hemerocallis species being infected (Jiang et al., 1993). Six Colletotrichum species have previously been reported as causal agent of anthracnose of Hemerocallis including $C$. dematium (Pers.) Grove on Hemerocallis sp. in the United States (Farr \& Rossman, 2011), C. gloeosporioides (Penz.) Penz. \& Sacc. on H. citrina in China (Gu et al., 2007), C. liliacearum Ferraris on H. fulva var. kwanso Regel in China (Jiang et al., 1993; Farr \& Rossman, 2011), C. lilii Plakidas ex Boerema \& Hamers on Hemerocallis sp. in the United States (Farr \& Rossman, 2011), C. spaethianum (Allesch.) Damm, P.F. Cannon, \& Crous, on Hemerocallis sp. in New Zealand, and Colletotrichum sp. (CBS 125338) on H. fulva in Canada (Damm et al., 2009). There is, however, little knowledge concerning the Colletotrichum species associated with Hemerocallis in China. The objective of this paper was to characterize Colletotrichum species associated with these plants in China based on morphology and multilocus DNA sequence data.

\section{MATERIALS AND METHODS}

\section{Isolation of Colletotrichum}

Dead leaves and stalks of Hemerocallis citrina, $H$. fulva, and $H$. fulva var. kwanso with anthracnose lesions were collected in Guizhou, Guangxi, and Liaoning provinces in China from 2008 to 2011 (Table 1). Single-spore isolates were obtained using the procedure described by Choi et al. (1999) and Chomnunti et al. (2011). Pure cultures were stored at $4^{\circ} \mathrm{C}$ on PDA slants. Isolates are deposited in Guizhou Academy of Agricultural Sciences, China, and the China General Microbiological Culture Collection Center (CGMCC).

\section{Morphological and cultural characterization}

Starter cultures were prepared by growing each isolate on PDA at $25^{\circ} \mathrm{C}$ in darkness for five days. Five replicate cultures of each isolate were prepared by aseptically cutting disks from the actively growing edge of the starter culture using a sterile cork borer. Each plug was placed onto PDA plates $(90 \mathrm{~mm} \times 15 \mathrm{~mm})$ and grown in alternating light and dark at $25^{\circ} \mathrm{C}$ (Sutton, 1980). To induce sporulation, plugs of actively growing mycelium were placed on to the surface 


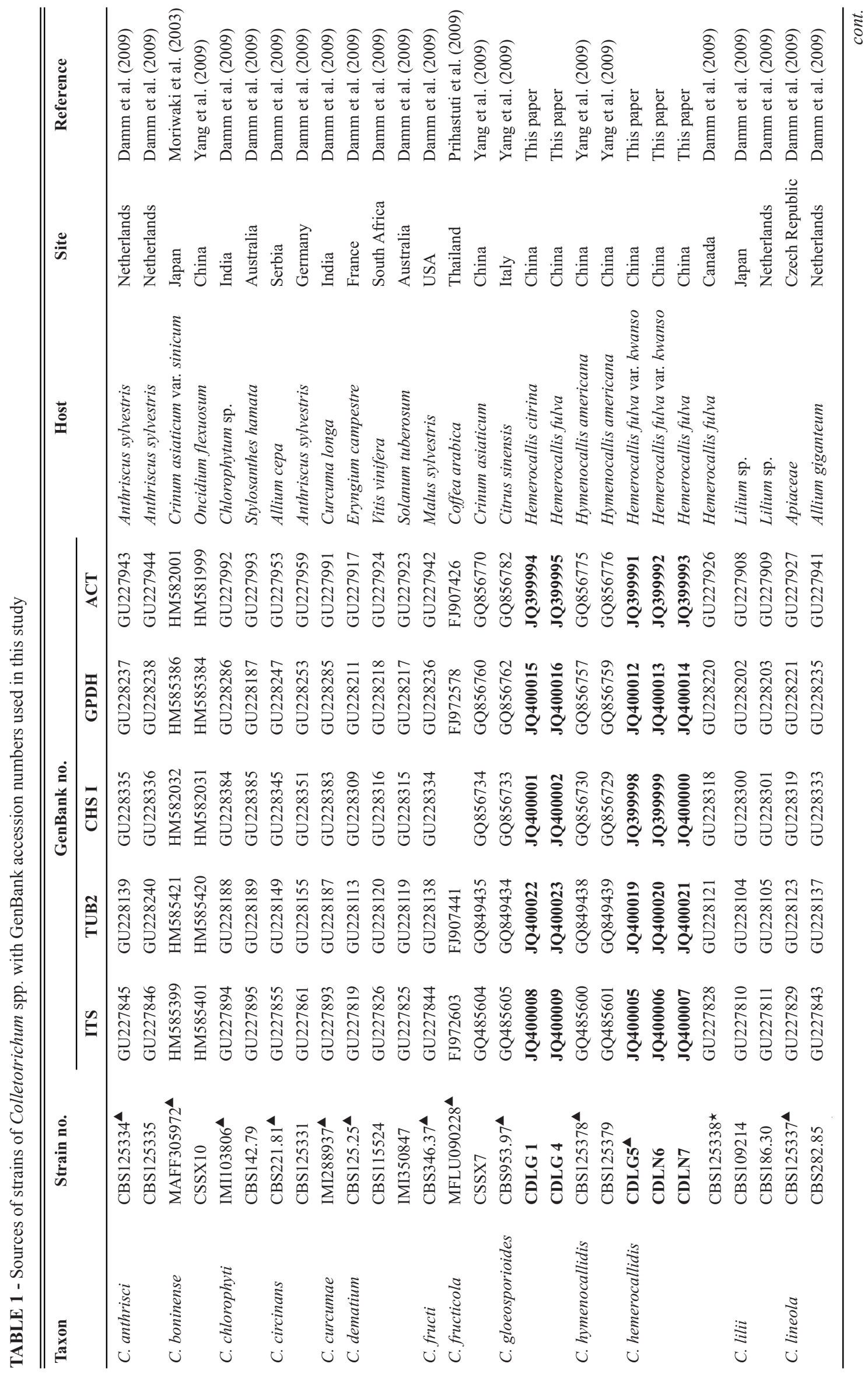




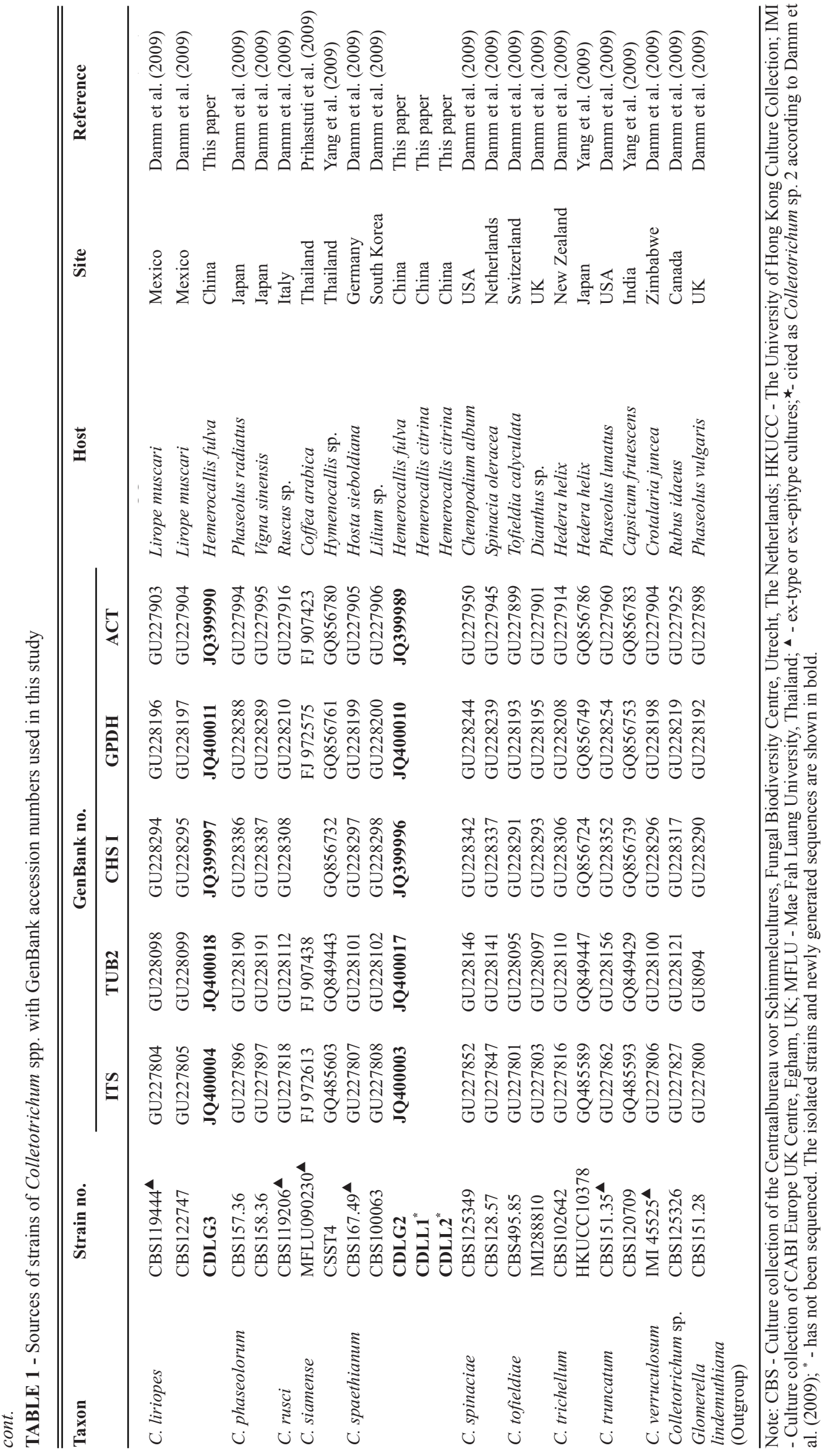


of synthetic nutrient-poor agar medium (SNA: $1 \mathrm{~g} \mathrm{KH}_{2} \mathrm{PO}_{4}$, $1 \mathrm{~g} \mathrm{KNO}_{3}, 0.5 \mathrm{~g} \mathrm{MgSO}_{4} \cdot 7 \mathrm{H}_{2} \mathrm{O}, 0.5 \mathrm{~g} \mathrm{KCl}, 0.2 \mathrm{~g}$ glucose, $0.2 \mathrm{~g}$ sucrose, $20 \mathrm{~g}$ agar, $1 \mathrm{~L}$ tap water) with autoclaved filter paper and double-autoclaved stems of Sium suave Walt. [(Apiaceae; comp. method proposed by Damm et al. (2009), using stems of Anthriscus sylvestris (L.) Hoffm., Apiaceae)] and incubated in the same conditions. Colony diameter was measured at day seven. After 7-10 days, the size and shape of 50 conidia harvested from the cultures were measured, and their mean and standard deviations (SD) were calculated. The colour of the conidial masses and zonation were recorded at day seven (Than et al., 2008). Mycelial appressoria were produced and measured using a slide culture technique (Sutton, 1980). Conidial appressoria were also induced by placing conidia in two drops of distilled water (about $1 \times 10^{12-14}$ conidia $/ \mathrm{mL}$ ) on a microscope slide, then placing the slide inside a Petri dish containing cotton moistened with distilled sterile water, and incubated at $25^{\circ} \mathrm{C}$ in darkness. After incubation for 24 hours, conidial appressoria formed by germ tubes were characterized.

\section{DNA extraction and sequencing}

DNA was extracted from the isolates grown on PDA at $25^{\circ} \mathrm{C}$ for $8-10$ days using a modified protocol of Chen et al. (2007). The partial sequence of the actin (ACT), beta-tubulin (TUB2), chitin synthase 1 (CHS I), glyceraldehyde-3-phosphate dehydrogenase (GPDH) gene, and $5.8 \mathrm{~S}$ nuclear ribosomal gene with the two flanking internal transcribed spacers (ITS) were amplified and sequenced using the primer pairs ACT-512F/ACT- 783R (Carbone \& Kohn 1999), T1/ Bt-2b (O’ Donnell \& Cigelnik 1997; Glass \& Donaldson 1995), CHS-79F/CHS -354R (Carbone \& Kohn 1999), GDF1/GDR1 (Guerber et al., 2003), and ITS-1/ITS-4 (White et al., 1990), respectively. The PCR amplifications were performed in a $25 \mu \mathrm{L}$ mixture containing $9.5 \mu \mathrm{L} \mathrm{ddH_{2 }} \mathrm{O}, 12.5 \mu \mathrm{L} 2 \times \mathrm{PCR}$ Master Mix (TIANGEN Co. China), $1 \mu \mathrm{L}$ of DNA template, $1 \mu \mathrm{L}$ of each primer $(10 \mu \mathrm{M})$. The reactions were performed with a thermal cycler (Mycler ${ }^{\mathrm{TM}}$, Bio-Rad, Hercules, CA, USA) using the thermal program described by Yang et al. (2009). PCR products were sequenced using the above-mentioned PCR primers and ABI BigDye v3.1 terminator sequencing chemistry according to the manufacturer's instructions of a BigDye ${ }^{\circledR}$ Terminator v3.1Cycle sequencing kit (Applied Biosystems, CA, USA) in an Applied Biosystems 3730xl DNA Analyzers at Sinomax Co., China.

\section{Molecular phylogenetic analysis}

Phylogenetic analysis was performed using the five gene regions cited above. The accession numbers of sequences generated are listed in Table 1. Multiple sequence alignments were generated using ClustalX 2.0.10 (Larkin et al., 2007) and manually adjusted to give the best fit with BioEdit 7.0.8.

A partition homogeneity test (PHT) was performed with 1000 replicates in PAUP 4.0b10 (Swofford, 2003) to evaluate statistical congruence among the five gene regions and each of the single and combined sequence alignments were analyzed using maximum parsimony (MP) in PAUP* 4.0b10. Ambiguously aligned regions were excluded from all analyses, and gaps were treated as missing data. Trees were inferred using the heuristic search option with tree bisection-reconnection (TBR) branch swapping and 1000 random sequence additions. Maxtrees were unlimited, branches of zero length were collapsed and all multiple parsimonious trees were saved. Clade stability of the trees resulting from the parsimony analyses were assessed by bootstrap analysis with 1000 replicates. Trees were visualized in Treeview. When analyzing single and combined sequences, some reference sequences were obtained from GenBank (Table 1). Sequences obtained in this study were submitted to GenBank (accession No: ACT, JQ399989- JQ399995; CHS I, JQ399996-JQ400002; ITS, JQ400003- JQ400009; GPDH, JQ400010- JQ400016; TUB 2, JQ400017-JQ400023), the alignment in TreeBASE (http://www.treebase.org/treebase/index.html, ID: 12294), and taxonomic novelties in MycoBank (Crous et al., 2004).

\section{RESULTS}

\section{Isolation of Colletotrichum species}

Nine isolates of Colletotrichum were obtained from recently dead or infected stalks and leaves of Hemerocallis citrina, H. fulva, and H. fulva var. kwanso in Guiyang, Nanning, and Dandong, China.

\section{Phylogenetic analysis}

The partition homogeneity test $(P=0.01)$ suggested that the individual gene partitions were not highly incongruent (Farris et al., 1995; Cunningham, 1997), thus the five gene datasets (ACT, CHS I, GPDH, ITS, TUB 2) from the Colletotrichum species plus datasets obtained from GenBank were combined for phylogenetic analysis. The combined datasets comprise 1797 characters after alignment, of which 700 characters are parsimony-informative, 991 constant, and 106 parsimony-uninformative. Parsimony analysis generated eight trees; SH test verified that they were similar, one of which (tree length $=2131$ steps, $\mathrm{CI}=0.605, \mathrm{RI}=0.88, \mathrm{RC}=0.532, \mathrm{HI}=0.395)$ is shown in Figure 1. Tree topologies obtained from the individual alignment of five genes and from the combined alignment are similar to each other, with only slight differences in bootstrap values, e. g. Colletotrichum spaethianum and C. lilii were not distinguished in two (ACT and ITS) of five phylogenies.

The phylogram constructed using combined datasets shows that the Chinese Hemerocallis isolates cluster into four distinct clades with high bootstrap support, presumably representing different Colletotrichum species. Sequences of the cultures CDLG2 and CDLG3 cluster with sequences of Colletotrichum spaethianum (CBS 167.49) and C. liriopes 


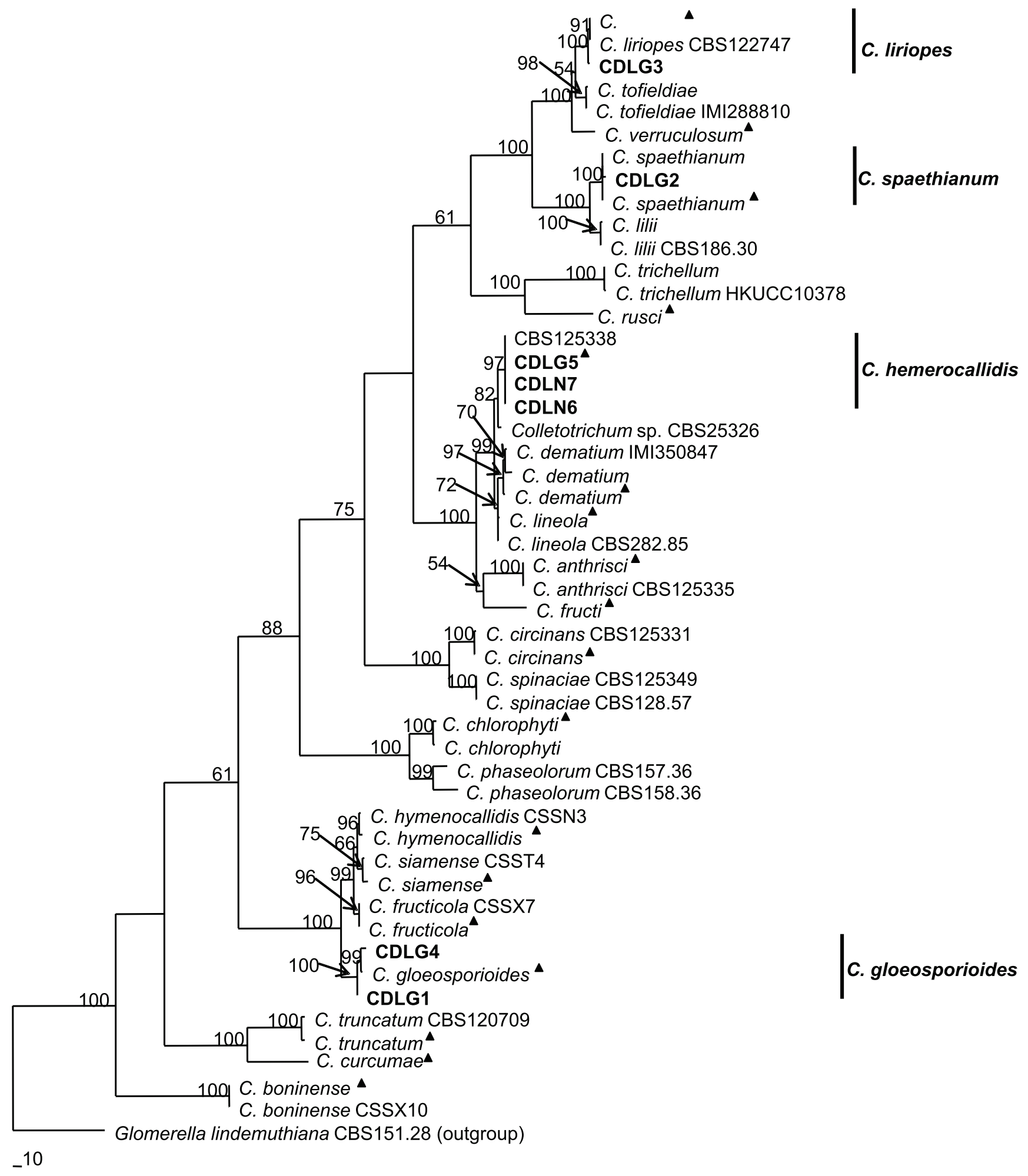

FIGURE 1 - Maximum parsimony phylogram inferred from combined partial ACT, CHS I, GPDH, ITS, and TUB 2 sequence data, showing phylogenetic relationships of Colletotrichum species isolated from Hemerocallis citrina, H. fulva, and $H$. fulva var. kwanso in China (tree length $=2131$ steps, $\mathrm{CI}=0.605, \mathrm{RI}=0.88, \mathrm{RC}=0.532, \mathrm{HI}=0.395$ ). Values above the branches are parsimony bootstrap data (equal or above 50\%). The tree is rooted with Glomerella lindemuthiana (CBS 151.28). ${ }^{\boldsymbol{}}$, ex-type or ex-epitype. 
(CBS 119444) with 100\% bootstrap support, respectively. Sequences of CDLG1, CDLG4, and Colletotrichum gloeosporioides epitype (CBS 953.57) are nested in a clade with $100 \%$ bootstrap support. Sequences of CDLG5, CDLN6, CDLN7, and CBS 125338 form a distinct clade with $100 \%$ bootstrap value (Figure 1).

\section{Taxonomy}

The nine strains isolated from Hemerocallis spp. represent four species based on DNA sequence analysis and morphological characteristics. Three strains represent one new species. The other six isolates represent three known Colletotrichum species which are presented with comments.

Colletotrichum gloeosporioides (Penz.) Penz. \& Sacc., Atti Inst. Veneto Sci. lett., ed Arti, Sér. 62: 670 (1884)

Colletotrichum gloeosporioides has been epitypified and can now be identified using sequence data (Cannon et al., 2008; Cai et al., 2009; Hyde et al., 2009; Phoulivong, 2011). In the present study this species was isolated from dead stalks of Hemerocallis citrina and H. fulva. Acervuli are black with pink conidia masses and setae are sparse. Based on morphological identification, Gu et al. (2007) reported that $C$. gloeosporioides caused severe anthracnose on Hemerocallis citrina leaves and this is confirmed here using morphological and molecular data. Fruit rots (anthracnose) have often been attributed to $C$. gloeosporioides with identifications based on morphological characteristics, but C. gloeosporioides is not a common pathogen on tropical fruits as shown by a recent study by Phoulivong et al. (2010).

Material examined: China, Guizhou province, Guizhou Academy of Agricultural Sciences, on recently dead flower stalk of Hemerocallis citrina, 10 June 2008, Y. L. Yang (GZAAS 080055, ex-living culture CDLG1); China, Guizhou province, Guiyang Botanical Garden of Medicinal Plants, on recently dead flower stalk of H. fulva, 1 July 2008, Y. L. Yang (GZAAS 080058, ex-living culture CDLG4).

Colletotrichum hemerocallidis Y. L. Yang, Zuo Y. Liu, K.D. Hyde \& L. Cai, sp. nov.

MycoBank: MB 564162

Etymology: Named after its host, Hemerocallis sp.

Holotype: China, Guizhou Province: Guiyang. On dead stalk of Hemerocallis fulva var. kwanso Regel, 1 July 2008, Y. L. Yang (GZAAS 080059; ex-holotype living culture CDLG5 = CGMCC 3.14971, CBS 130642).

On host, acervuli elliptical to circular, arranged irregularly, subepidermal, disrupting outer epidermal cell wall of host, setae present (Figure 2A). Setae 71.5-130.5 $\times$ 7-12 $\mu \mathrm{M}$, dark brown, opaque, 2- to 4-septated, base inflated, tip acute (Figure 3). Conidiophores hyaline, pale brown at base, cylindrical, 1- to 2-celled, branched, 12-
$19.5(-25.5) \times 3-5 \mu \mathrm{M}$, mean $\pm \mathrm{SD}=15.6 \pm 3.4 \times 4.2 \pm 0.5$ $\mu \mathrm{M}(\mathrm{n}=20)$ (Figure 3$)$, conidiogenous cells cylindrical to ampulliform, hyaline, 9-19 $(-24) \times 3.5-5 \mu \mathrm{M}$, mean $\pm \mathrm{SD}=$ $14.1 \pm 3.5 \times 4.3 \pm 0.5 \mu \mathrm{M}(\mathrm{n}=20)$. Conidia slightly curved, often straight on one side and slightly curved on the other, hyaline, (17.5-) $20.5-27 \times 3.5-5 \mu \mathrm{M}$, mean $\pm \mathrm{SD}=23.2 \pm 2 \times$ $4.1 \pm 0.3 \mu \mathrm{M}(\mathrm{n}=30)$, base truncate, apex acute (Figure $2 \mathrm{C})$.

In culture: Colonies on PDA, attaining 4.9-6.7 cm, mean $\pm \mathrm{SD}=6.1 \pm 0.5 \mathrm{~cm}(\mathrm{n}=15)$ diam. in seven days at $25^{\circ} \mathrm{C}$. Aerial mycelium sparse, white to grey, flat with entire margin, reverse greenish black. Sclerotia present, globose to subglobose, without setae. Conidia not produced. Colonies on SNA, attaining 4.8-6.1 cm, mean $\pm \mathrm{SD}=5.5 \pm 3.7 \mathrm{~cm}$ $(\mathrm{n}=15)$ diam. in seven days at $25^{\circ} \mathrm{C}$. Aerial very sparse, grey. Sclerotia absent; Conidia not produced.

On Sium suave stem: acervuli abundant (Figure 2B), setae dark brown to black, opaque, smooth, septation hardly visible, 76.5-152.5 $\times 5-11.5 \mu \mathrm{M}$, tapered from base to apex. Conidiophores pale brown, 1-to 3-septate, branched, 16.5$40(-44.5) \times 3.5-5 \mu \mathrm{M}$, mean $\pm \mathrm{SD}=28.1 \pm 8.3 \times 4.3 \pm 0.5$ $\mu \mathrm{M}(\mathrm{n}=20)$ (Figure 4). Conidiogenous cells pale brown, cylindrical to elongate ampulliform, 7-16.5 (-19) $\times$ 3.5-5.5 $\mu \mathrm{M}$, mean $\pm \mathrm{SD}=12.3 \pm 3.3 \times 4.5 \pm 0.6 \mu \mathrm{M}(\mathrm{n}=20)$. Conidia in white to yellowish masses, hyaline, smoothwalled, aseptate, one side straight and the other slightly curved, apex acute or slightly rounded, base truncate, 23 $31.5(-33.5) \times 3.5-5.5 \mu \mathrm{M}$, mean $\pm \mathrm{SD}=27.8 \pm 2.3 \times 4.6 \pm$ $0.4 \mu \mathrm{M}(\mathrm{n}=150)$ (Figure $2 \mathrm{I})$. Mycelial appressoria clavate, brown, margin entire, sometimes slightly lobed, 6.5-16 $(-18.5) \times 5-9 \mu \mathrm{M}$, mean $\pm \mathrm{SD}=11.7 \pm 2.9 \times 6.5 \pm 1.1 \mu \mathrm{M}$ $(\mathrm{n}=50)$ (Figures 2D, E), usually in loose groups; Conidial appressoria clavate to irregular, brown, margin entire to crenate, sometimes deeply lobed, 6.5-13 $\times$ 4-9.5 $\mu \mathrm{M}$, mean $\pm \mathrm{SD}=9.4 \pm 1.4 \times 6.4 \pm 1.2 \mu \mathrm{M}(\mathrm{n}=60)$ (Figures 2F, G, H).

Known hosts and distribution: Hemerocallis fulva, Hemerocallis fulva var. kwanso, Guizhou and Guangxi provinces, China.

Additional specimens examined: China, Guangxi province, Nanning, on leaf spot of Hemerocallis fulva var. kwanso, 19 June 2008, Y. L. Yang (GZAAS 080040, living culture CDLN6); China, Guangxi province, Nanning, on leaf spot of Hemerocallis fulva, 19 June 2008, Y. L. Yang (GZAAS 080041, living culture CDLN7).

Notes: The conidial shape of $C$. hemerocallidis is similar to that of $C$. anthrisci Damm, P.F. Cannon \& Crous, and $C$. lineola Corda, while the conidial width and mycelial appressoria of $C$. hemerocallidis are different from those of $C$. anthrisci and $C$. lineola. The conidia of $C$. hemerocallidis are wider than those of the latter (3.5-5.5 $\mu \mathrm{m}$ vs. 3-4 $\mu \mathrm{m})$. The mycelial appressoria of $C$. hemerocallidis are clavate with entire or sometimes slightly lobed margins, while those of $C$. anthrisci are navicular, bullet-shaped to clavate, and those of $C$. lineola ellipsoidal to clavate (Damm et al., 2009). In multilocus phylograms, sequence data of C. anthrisci, C. hemerocallidis, and C. lineola indicate positions nested in different clades (Figure 1). 

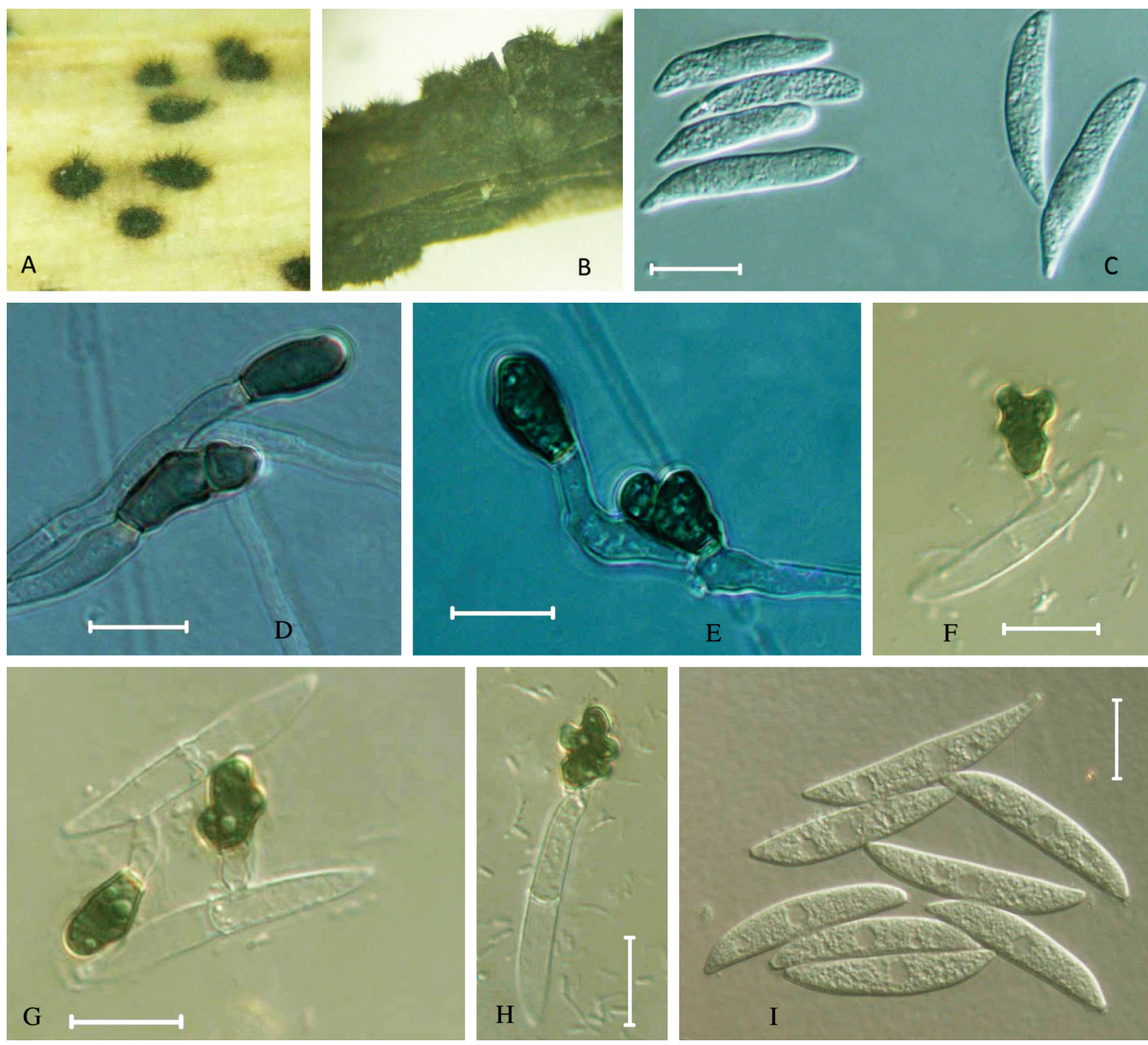

FIGURE 2 - Colletotrichum hemerocallidis (holotype). A and B, acervuli, A. on stem of Hemerocallis fulva var. kwanso; B. on a stem of Sium suave; C and I. conidia, C. on H. fulva var. kwanso; I. on Sium suave; D and E. mycelial appressoria; F, G, and H. conidial appressoria. Bars $=10 \mu \mathrm{M}$.

Colletotrichum liriopes Damm, P.F. Cannon \& Crous This taxon was isolated from a dead stalk of Hemerocallis fulva, acervuli are small with short black setae.

Material examined: China, Guizhou Province: Guiyang Botanical Garden of Medicinal Plants. On recently dead flower stalk of Hemerocallis fulva, 1 July 2008, Y. L. Yang (GZAAS 080057, living culture CDLG3).

Note: This taxon was first reported from Liriopes muscari (Decne.) L. H. Bailey in Mexico (Damm et al., 2009). We also collected this species from anthracnose on Eria coronaria (Lindl.) Rchb. F. (Orchidaceae) and a healthy root of Pleione bulbocodioides (Franch.) Rolfe
(Orchidaceae) (Yang et al., 2011), so this species is not host-specific.

Colletotrichum spaethianum (Allesch.) Damm, P.F. Cannon \& Crous

This species was isolated from anthracnose of Hemerocallis fulva, causing brown spots on leaves and having small acervuli containing black setae.

Material examined: China, Guizhou Province: Guiyang Botanical Garden of Medicinal Plants. On leaf spot of Hemerocallis fulva, 1 July 2008, Y. L. Yang (GZAAS 080056, living culture CDLG2). China, Liaoning Province: on leaf spot of Hemerocallis citrina, 


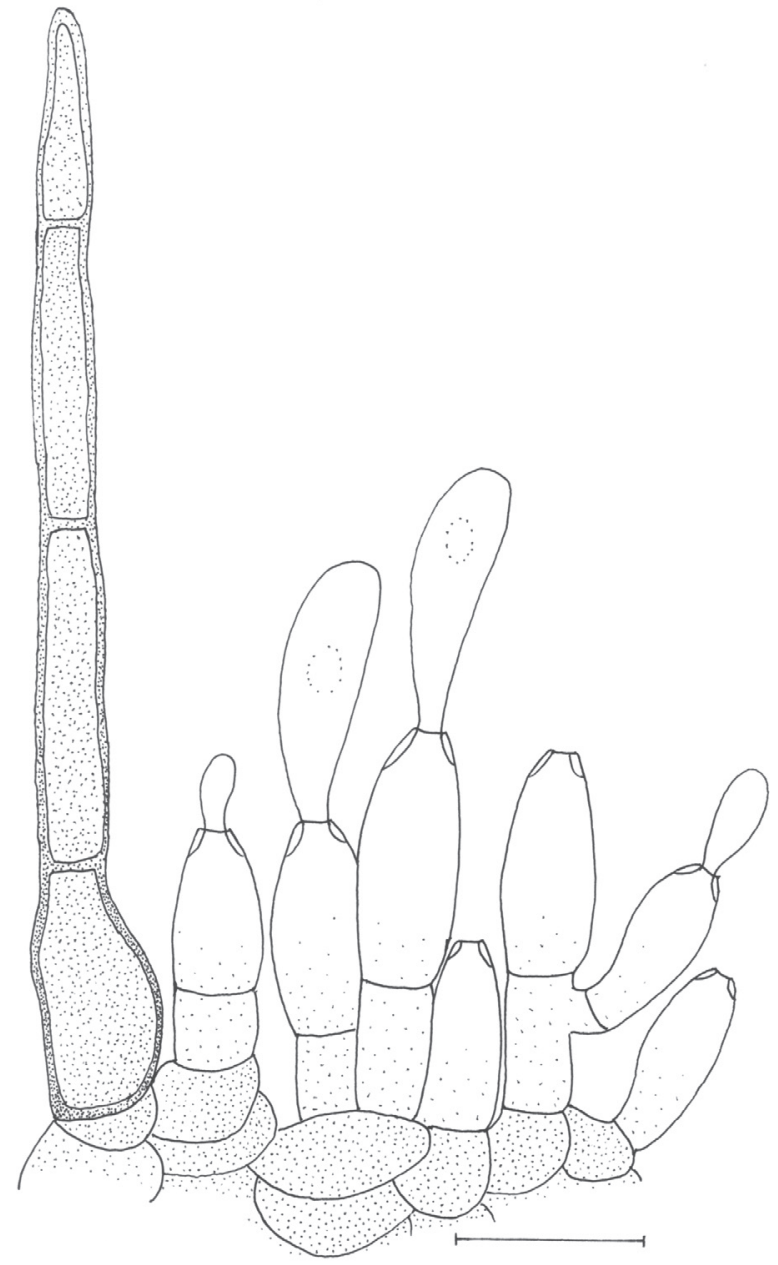

FIGURE 3 - Seta and conidiophores of Colletotrichum hemerocallidis (holotype) on H. fulva var. kwanso. Bar $=10 \mu \mathrm{M}$.

4 July 2011, Y. L. Yang (GZAAS 110007, living culture CDLL1; GZAAS 110008, living culture CDLL2).

Note: Damm et al. (2009) reported Colletotrichum spaethianum from dead stems of Hosta sieboldiana (Lodd.) Engl., leaf spot of Hemerocallis sp., and infected leaf of Lilium sp. Yang et al. (2009) also isolated this species from a leaf spot of Hymenocallis americana (Jacq.) Salisb. This suggests a broad host range for this species.

\section{DISCUSSION}

Six species of Colletotrichum have previously been reported from Hemerocallis species, but with the exception of C. spaethianum (CBS 101631) and Colletotrichum sp. (CBS 125338) which have been sequenced, the identifications were based on morphological characteristics (Table 2). In the context of the present study, the species of Colletotrichum

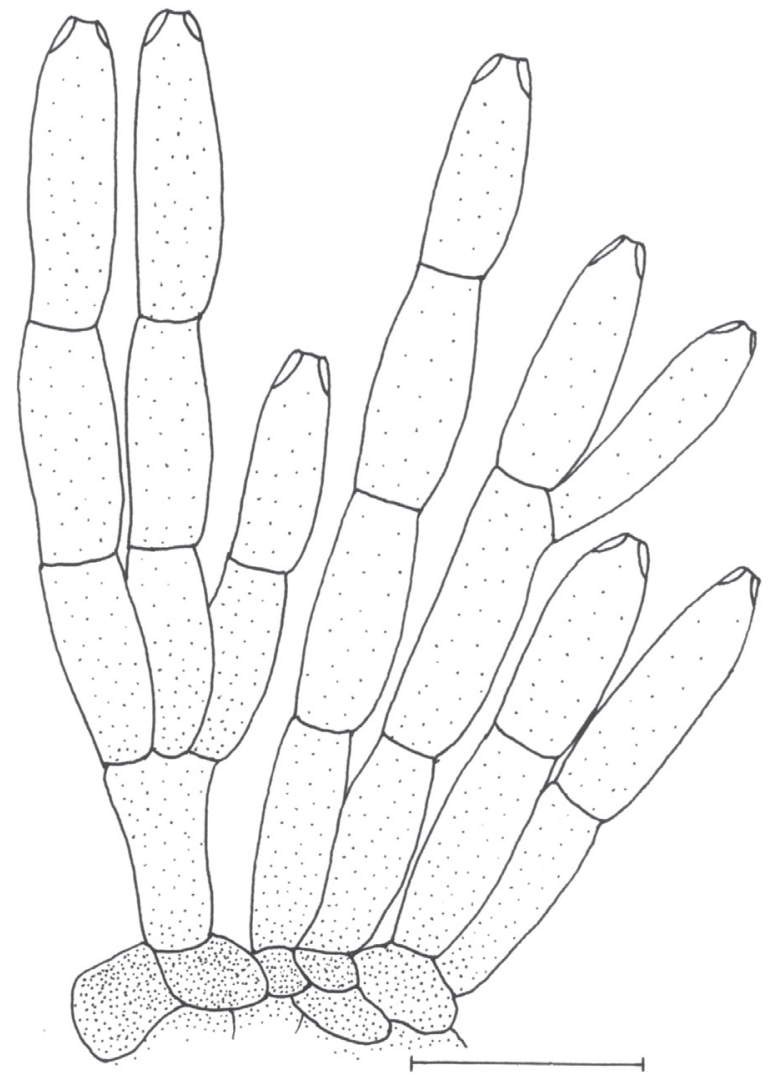

FIGURE 4 - Conidiophores of Colletotrichum hemerocallidis (holotype) on Sium suave. Bar $=10 \mu \mathrm{M}$.

on Hemerocallis spp. in China are accurately identified and data are provided extending our knowledge on the host range and distribution of four species. One new species is proposed. Several studies have shown the importance of using sequence data when identifying Colletotrichum species, because wrong diagnosis may otherwise result (Phoulivong et al., 2010; Damm et al., 2010; Cai et al., 2011; Ko Ko et al., 2011).

Colletotrichum hemerocallidis apparently is saprobic and pathogenic on $H$. fulva. This suggests that $C$. hemerocallidis is similar to some other Colletotrichum species (e.g. C. gloeosporioides, C. liriopes, C. spaethianum) in having more than one biological life strategy (Damm et al., 2009; Rojas et al., 2010; Yang et al., 2011; Phoulivong, 2011). As we gain more knowledge on the distribution and host range of Colletotrichum species, it appears that many species may be saprobes, endophytes, or pathogens, having a wide host range and distribution. The new strains of Colletotrichum gloeosporioides obtained during this study were isolated from symptomatic tissues of Hemerocallis thus suggesting these strains are pathogens of this genus. 
TABLE 2 - Colletotrichum species known from Hemerocallis spp.

\begin{tabular}{|c|c|c|c|c|}
\hline Species & Host & Country & Strain & Reference \\
\hline Colletotrichum dematium & Hemerocallis sp. & Zimbabwe & Unknown & Farr \& Rossman (2011) \\
\hline C. gloeosporioides/ & H. citrina & China & Unknown & Gu et al. (2007) \\
\hline \multirow[t]{3}{*}{ Glomerella cingulata } & & China & CDLG1 & This study \\
\hline & & Brunei Darussalam & Unknown & Farr \& Rossman (2011) \\
\hline & H. fulva & China & CDLG4 & This study \\
\hline \multirow[t]{3}{*}{ C. hemerocallidis } & H. fulva var. kwanso & China & CDLG5, CDLN6 & This study \\
\hline & H. fulva & China & CDLN7 & This study \\
\hline & H. fulva & Canada & CBS $125338^{\star}$ & Damm et al. (2009) \\
\hline \multirow[t]{2}{*}{ C. liliacearum" } & Hemerocallis sp., & USA & Unknown & Farr \& Rossman (2011) \\
\hline & H. fulva var. kwanso & China & Unknown & Jiang et al. (1993) \\
\hline C. lilii & Hemerocallis sp. & USA & Unknown & Farr \& Rossman (2011) \\
\hline C. liriopes & H. fulva & China & CDLG3 & This study \\
\hline \multirow[t]{3}{*}{ C. spaethianum $\bullet$} & H. citrina & New Zealand & CBS $101631^{\bullet}$ & Damm et al. (2009) \\
\hline & & China & CDLL1, CDLL2 & This study \\
\hline & H. fulva & China & CDLG2 & This study \\
\hline
\end{tabular}

Note: ", a synonym of Colletotrichum spaethianum according to Damm et al. (2009); ${ }^{\bullet}$, previously reported as C. capsici (CBS 101631$),{ }^{\star}$, cited as Colletotrichum sp. 2 by Damm et al. (2009).

\section{ACKNOWLEDGEMENTS}

This project was supported by the National Natural Science Foundation of China (No. 31070025) and Guizhou Science and Technology Department [No. (2010) 4002-1]. The National Research Council of Thailand awarded grant No. 5420102003 to study the genus Colletotrichum. Lei Cai acknowledges grants CAS KSCX2-YW-Z-1026 and NSFC 31110103906. This work was also supported by a grant from the National Plan of Science and Technology, King Abdulaziz City of Science and Technology, Riyadh, Saudi Arabia (10-Bio-965-02).

\section{REFERENCES}

Cai L, Hyde KD, Taylor PWJ, Weir BS, Waller J, Abang MM, Zhang JZ, Yang YL, Phoulivong S, Liu ZY, Prihastuti H, Shivas RG, McKenzie EHC, Johnston PR (2009) A polyphasic approach for studying Colletotrichum. Fungal Diversity 39:183-204.

Cai L, Udayanga D, Manamgoda DS, Maharachchikumbura SSN, Mckenzie EHC, Guo LD, Liu XX, Bahkali AH, Hyde KD (2011) The need to carry out a re-inventory of plant pathogens. Tropical Plant Pathology 36:205-213.

Cannon PF, Buddie AG, Bridge PD (2008) The epitypification of Colletotrichum gloeosporioides. Mycotaxon 104: 189-204.

Carbone I, Kohn LM (1999) A method for designing primer sets for speciation studies in filamentous ascomycetes. Mycologia 91:553556.

Chen J, Xu LL, Liu B, Liu XZ (2007) Taxonomy of Dactylella complex and Vermispora. I. Generic concepts based on morphology and ITS sequences data. Fungal Diversity 26:73-83.

Choi YW, Hyde KD, Ho WWH (1999) Single spore isolation of fungi. Fungal Diversity 2:29- 38.

Chomnunti P, Schoch CL, Aguirre-Hudson B, Ko-Ko TW, Hongsanan
S, Jones EB, Kodsueb R, Phookamsak R, Chukeatirote E, Bahkali AH, Hyde KD (2011) Capnodiaceae. Fungal Diversity 51:103-134.

Crous PW, Gams W, Stalpers JA, Robert V, Stegehuis G (2004) MycoBank: an online initiative to launch mycology into the 21st century. Studies in Mycology 50:19-22.

Cunningham CW (1997) Can three incongruence tests predict when data should be combined? Molecular Biology and Evolution 14:733740 .

Damm U, Woudenberg JHC, Cannon PF, Crous PW (2009) Colletotrichum species with curved conidia from herbaceous hosts. Fungal Diversity 39:45-87.

Damm U, Baroncelli R, Cai L, Kubo Y, O'Connell R, Weir B, Yoshino K, Cannon PF (2010) Colletotrichum: species, ecology and interactions. Journal of Microbiology and Antimicrobials - Fungus 2:161-165.

Farr DF, Rossman AY (2011) Fungal Databases, Systematic Mycology and Microbiology Laboratory, ARS, USDA. Available at: http://nt.arsgrin.gov/fungaldatabases. Accessed on September 10, 2011.

Farris JS, Kallersjo M, Kluge AG, Bult C (1995) Testing significance of incongruence. Cladistics 10:315-319.

Glass NL, Donaldson GC (1995) Development of primer sets designed for use with the PCR to amplify conserved genes from filamentous ascomycetes. Applied and Environmental Microbiology 61:1323-1330.

Gu JY, Xi PG, Li MH, Jiang ZD (2007) Descriptions of pathogenic fungi on six wild vegetables in Guangzhou Region. Jounal of Huazhong Agricultural University 26:41-45. (In Chinese)

Guerber JC, Liu B, Johnston P, Correll JC (2003) Characterization of diversity in Colletotrichum acutatum sensu lato by sequence analysis of two introns, mtDNA and intron RFLPs, and mating compatibility. Mycologia 95:872-895.

Hyde KD, Cai L, Cannon PF, Crouch JA, Crous PW, Damm U, Goodwin PH, Chen H, Johnston PR, Jones EBG, Liu ZY, McKenzie EHC, Moriwaki J, Noireung P, Pennycook SR, Pfenning LH, Prihastuti H, Sato T, Shivas RG, Tan YP, Taylor PWJ, Weir BS, Yang YL, Zhang JZ (2009) Colletotrichum - names in current use. Fungal 
Diversity 39:147-183.

Jiang FL, Niu YM, Gu WQ (1993) Studies on anthracnose of Hemerocallis. Journal of Zhejiang Forestry College 10:23-29. (In Chinese)

Ko Ko TW, Mckenzie EHC, Bahkali AH, To-Anun C, Chukeatirote E, Promputtha I, Abd-Elsalam KA, Soytong K, Wulandari NF, Sanoamuang N, Jonglaekha N, Kobsueb R, Cheewangkoon R, Wikee S, Chamyuang S, Hyde KD (2011) The need for re-inventory of Thai phytopathogens. Chiang Mai Journal of Science 38:1-13.

Larkin MA, Blackshields G, Brown NP, Chenna R, McGettigan PA, McWilliam H, Valentin F, Wallace IM, Wilm A, Lopez R, Thompson JD, GibsonTJ, Diggins DG (2007) Clustal W and Clustal X. version 2.0. Bioinformatics 23:2947-2948.

Ma HF, Meng SM, Zhao HD, Liu JL (2010). Study on extraction of flavonoids from Hemerocallis fulva by microwave. Shanxi Chemical Industry 30:28-33. (In Chinese)

Moriwaki J, Sato T, Tsukiboshi T (2003) Morphological and molecular characterization of Colletotrichum boninense sp. nov. from Japan. Mycoscience 44:47-53.

Munson RW (1989) Hemerocallis, the Daylily Journal. Portland OR. Timber Press.

O’Donnell K, Cigelnik E (1997) Two divergent intragenomic rDNA ITS2 types within a monophyletic lineage of the fungus Fusarium are nonorthologous. Molecular Phylogenetics and Evolution 7:103-116.

Phoulivong S, Cai L, Chen H, McKenzie Eric HC, Abdelsalam K, Chukeatirote E, Hyde KD (2010) Colletotrichum gloeosporioides is not a common pathogen on tropical fruits. Fungal Diversity 44:33-43.

Phoulivong S, Cai L, Parinn N, Chen H, Abd-Elsalam KA, Chukeatirote E, Hyde KD (2010) A new species of Colletotrichum from Cordyline fruticosa and Eugenia javanica causing anthracnose disease. Mycotaxon114:247-257.

Phoulivong S (2011) Colletotrichum, naming, control, resistance, biocontrol of weeds and current challenges. Current Research in Environmental \& Applied Mycology 1:53-73.

Prihastuti H, Cai L, Chen H, McKenzie EHC, Hyde KD (2009) Characterization of Colletotrichum species associated with coffee berries in northern Thailand. Fungal Diversity 39:89-109.

Rojas EI, Rehner SA, Samuels GJ, Van Bael SA, Herre EA, Cannon P, Chen R, Pang JF, Wang RW, Zhang YP, Peng YQ, Sha T (2010)
Colletotrichum gloeosporioides s. 1. associated with Theobroma cacao and other plants in Panama: Multilocus phylogenies distinguish host-associated pathogens from asymptomatic endophytes. Mycologia 102:1318-1338.

Staples GW, Kristiansen MS (1999) Ethnic culinary herbs: A guide to identification and cultivation in Hawaii. Honolulu HI. University of Hawaii Press.

Sutton BC (1980) The coelomycetes. Fungi imperfecti with pycnidia, acervuli and stromata. Kew UK. Commonwealth Mycological Institute.

Swofford DL (2003) PAUP*: phylogenetic analysis using parsimony (*and other methods). Version 4b10. Sunderland MA. Sinauer Associates.

Than PP, Jeewon R, Hyde KD, Pongsupasamit S, Mongkolporn O, Taylor PWJ (2008) Characterization and pathogenicity of Colletotrichum species associated with anthracnose disease on chilli (Capsicum spp.) in Thailand. Plant Pathology 57:562-572.

Tomkins JP, Wood TC, Barnes LS, Westman A, Wing RA (2010) Evaluation of genetic variation in the daylily (Hemerocallis spp.) using AFLP markers. Plant Cell, Tissue and Organ Culture 102:199204.

White TJ, Bruns T, Lee S, Taylor J (1990) Amplification and direct sequencing of fungal ribosomal RNA genes for phylogenetics. In: Innis MA, Gelfand DH, Sninsky JJ, White TJ (Eds.) PCR Protocols: a guide to methods and applications. San Diego CA. Academic Press. pp. 315-322.

Yang YL, Liu ZY, Cai L, Hyde KD, Yu ZN, McKenzie EHC (2009) Colletotrichum anthracnose of Amaryllidaceae. Fungal Diversity 39:123-146.

Yang YL, Cai L, Yu ZN, Liu ZY, Hyde KD (2011) Colletotrichum species on Orchidaceae in southwest China. Cryptogamie Mycologie 32:229-253.

Zhang YZ, Chen T (2008) Study on growth and nutrient uptake characteristics of major cultivars of daylily in Hunan Province. Crop research 22:95-100. (In Chinese)

Zhou TL, Wang KZ, Zhang GZ, Du YS (1994) Ananlysis of isoperoxidase of 36 day lily kinds. Acta Botanica Boreali-Occidentalia Sinica 14:122-126. (In Chinese)

Zhu PF, Zhang LX, Liu L (2008) Compatibility and hybridus embryos culture in vitro between Hemerocallis hybridus and H. citrina. Northern Horticulture 8:190-191. (In Chinese)

TPP 487 - Received 16 January 2012 - Accepted 25 April 2012 Section Editor: Meike Piepenbring 